Journal of Universal Language 7

March 2006, 139-160

\title{
The Universal Tendency for Renewal among Grammatical Expressions for Anterior and Related Aspect
}

\author{
Aaron Smith \\ Illinois State University
}

\begin{abstract}
This study investigates the synchronic distribution of grammatical expressions (grams) along the path of grammaticization for anterior and diachronically related senses. I use the synchronic distribution of these grams as a means of inferring their diachronic behavior, particularly in terms of renewal, defined as the 'refilling' of a given semantic domain in the on-going process of grammaticization. The data support the hypothesis that there is a robust tendency for renewal among grams expressing anterior and related senses and therefore suggests certain stability in the shape of tense/aspect systems in the languages of the world, at least for this set of grams.
\end{abstract}

Keywords: grammaticization, diachrony, tense/aspect, layering, renewal

\section{Introduction}

When we look at the distribution of grammatical categories in 
the languages of the world, we see that it is asymmetrical, in the sense that certain grams and gram types have a tendency to occur robustly in some languages while being completely absent in others. ${ }^{1}$ It does not appear to be equally probable that any gram will develop in any language. In other words, there seems to be some force at work encouraging the development of grams in some languages while inhibiting that development in others.

The data in the Gramcats Database (housed at the University of New Mexico), a stratified probability sampling of 76 languages proportionally representative of every language phylum in the world of known languages shows this statistical skewing most clearly. ${ }^{2} \mathrm{We}$ get a good sense of the asymmetrical distribution of grammatical expressions among the languages in Gramcats by looking at the grams indicating some specific meaning, such as anterior, referring to events or situations in the past that carry relevance into the present, e.g., I have known her since school. In Gramcats, there are 57 forms expressing such anterior meaning. Of these 57 forms, 34 of them appear in a language with more than one anterior expression, such that only 39 of the 76 languages in the database, or slightly more than half, have an anterior gram. Furthermore, three of the 39 languages have more than two such grammatical expressions, with Margi, a Western Chadic language, having five. The asymmetry in this distribution pattern is obvious because in a symmetrical distribution, we would expect the 57 forms to be spread out more evenly over 57 languages; we would not expect that 34 of those expressions, or $60 \%$, would cluster in a subset of languages, with one of those languages having as many as five different expressions

\footnotetext{
${ }^{1}$ Following Bybee et al. (1994), I use the term gram as an abbreviation for grammatical morpheme.

2 I am grateful to Joan Bybee for generous use of the Gramcats database in researching this project. Much of the raw data presented here, however, can be found in Bybee, Perkins \& Pagliuca (1994). Any errors in the analysis, however, are my own.
} 
for anterior meaning. The asymmetry among expressions of anterior meaning is found in other verbal domains as well. ${ }^{3}$

In this paper, I study grams expressing anterior and related meanings in terms of their diachronic relationships. As the data from this study will suggest, the skewed distribution of grams for anterior and related senses in the languages of the world is due to a greater tendency for a language to "renew" grammatical categories of anterior and its diachronically related senses with newly emerging forms and that concomitantly innovation of new anteriors or diachronically related senses in a language where such meanings did not exist previously is less likely, although not impossible. The propensity for renewal over innovation has the effect of maintaining an asymmetrical distribution of anterior and related grams over time and constraining the random development of such grams in languages of the world.

\section{Renewal}

Renewal is a concept of language change going back at least to the $19^{\text {th }}$ century (see for instance Gablentz 1891, Meillet 1912, Hodge 1970), and it is defined as the refilling of a semantic domain with new phonetic material, often a periphrastic construction, thus renewing the expressivity of that domain after the natural forces of

\footnotetext{
3 As another example, Grams expressing progressivity, i.e., on-going activity at the moment of speech, are found in 47 of the 76 languages of the database, or roughly, $62 \%$ of the languages. Even within this subset of 47 languages, progressive grams show a tendency to cluster in certain languages. For instance, while the language Cocama (Andean-Equatorial) has only 1 gram expressing progressive meaning, Ngambay (Nilo-Saharan) has 4. In all, of the 47 languages with a progressive gram, 27, or more than half, show multiple grams for progressive meaning.
} 
language change have weakened its semantic content. ${ }^{4}$

An oft-cited example of renewal is the successive development of expressions for future in English. In the oldest English texts, future is most often expressed by a morphologically present form, sometimes modified by a future-time adverbial expression (Mitchell 1985: 238), as shown in (1).
(1) ponne cume ic to $\mathrm{e}$ and pec ponon then come.PRES I to you and you.ACC thence ham lædo. home lead.PRES

'Afterwards I will come to you and thence lead you home.'

(quoted from Bede in Mitchell 1985: 238)

Also in Old English texts, however, we see the beginnings of a future periphrasis expressed with the Old English verb sculan, originally meaning 'owe, ought', used to signal future (Bybee \& Pagliuca 1991, Fleischman 1982), an early attestation of which is shown in (2).

(2) All gelic gie sciolon losiga. ${ }^{5}$ all alike you shall perish

'All of you alike shall perish.' (the Lindisfarne Gospel, Luke xiii. 5 in the OED, on-line edition)

In later $\mathrm{OE}$ and $\mathrm{ME}$, we find the use of another auxiliary, will (from OE willan 'to want'), to signal future as well, as seen in (3).

\footnotetext{
${ }^{4}$ The notion of refilling here is not meant to suggest gaps in the grammar that must, in any sense, be refilled by grammaticizing elements.

5 The futurity of sciolon losiga is evidenced by the fact that it is a translation of the Latin future, peribitis (OED, On-line Edition).
} 
(3) Mycel yfel de se unwritere, gyf much evil does the bad writer if he nele $^{6}$ his who gerihtan. he neg.will his error correct

'The bad writer does much evil if he will not correct his error.' (Ælric’s Grammar, edited by Zupitza (1980: 3)) ${ }^{7}$

While in American English, will has ousted shall in nearly all contexts, British English and some extra-territorial varieties have maintained a semantic distinction between shall and will, the former being a more general future and the latter expressing a slight sense of volition (Quirk et al. 1985: 228-231), a retention of its OE meaning. Additionally, English has seen the development of another future periphrasis in the [be going to + Verb] construction which has come to signal a more definite future than either shall or will, in the sense that the verb in the be going to construction is more planned or definite; an example is given in (4) from the Early Modern Period from Shakespeare's Two Gentlemen of Verona.

(4)

$\begin{array}{ll}\text { Duke: } & \text { Sir Valentine, whither away so fast? } \\ \text { Sir Valentine: } & \text { Please it your grace, there is a messenger } \\ & \text { That stays to bear my letters to my friends } \\ & \text { And I am going to deliver them. }\end{array}$

(Hopper \& Traugott 2003: 89)

Thus in English, there have been three successive developments of futurity over its history, representing waves of renewal. The example of renewal among English futures shows an important aspect of the process, specifically that renewal does not necessarily

\footnotetext{
${ }^{6}$ Nele is a common OE contraction for $n e$ 'not' + willan 'want/will'.

${ }^{7}$ Nele gewihtan is the translation of the Latin future perfect correxerit 'will have corrected'.
} 
entail loss of the older expression as the new expression develops. Instead, older and newer senses may overlap or layer (Hopper 1991) at a given synchronic stage. Thus, layering is essentially the synchronic reflex of the diachronic process of renewal and is thus an important heuristic for this study since layering implies renewal. In addition to layering, renewal is also inferable from certain facts concerning the distribution of diachronically related grams, a topic I turn to in the next section.

\section{Anterior Meaning in Diachrony}

The most fundamental reason why the distribution of grammatical expressions is not random in language is that the semantic content of those expressions is not random. Sequences of grammatical categories are linked historically through a fine gradation of semantic nuance. These graded semantic meanings are diachronically fixed and related to one another such that the temporally former designation is semantically more specific than the latter. A given grammatical expression moves unidirectionally over time from one of these meaning categories to the next, so that as that expression develops in the language, it becomes more and more general. ${ }^{8}$ In the literature,

\footnotetext{
${ }^{8}$ In the literature on grammaticization, there is some debate regarding the directionality of development on paths of grammaticization. One position would be the strong unidirectionality claim in which all change is taken to be unidirectional; however I know of no one who takes this position. The more reasonable view, and the one taken by most working in grammaticization studies, including myself, is the softer claim that unidirectionality is a theoretically important principle, and one that is true most of the time. This position acknowledges that apparent reversals exist and that those reversals are interesting because they reveal something about language and language change (Dahl 2000: 12, Traugott $\&$ Dasher 2002). Some who have acknowledged the ubiquity of unidirectionality, still, however, claim that the few apparent counter examples are enough to dismiss unidirectionality as an important construct in a theory of language change (see the collection of papers in Campbell 2001 and Newmeyer 1998).
} 
these diachronic strands of unidirectionally related meanings have come to be known as clines (Hopper \& Traugott 2003), chains (Heine, Claudi \& Hünnemeyer 1991), or, as I will refer to them here, paths (Bybee, Perkins \& Pagliuca 1994). In this section I consider the relationship between anterior grams and grams expressing diachronically related meanings, which we will then use to observe the phenomenon of layering, and thereby renewal. One such path, which I call the anterior path, is shown in (5).

(5) The Anterior Path of Grammaticization

(Bybee et al. 1994)

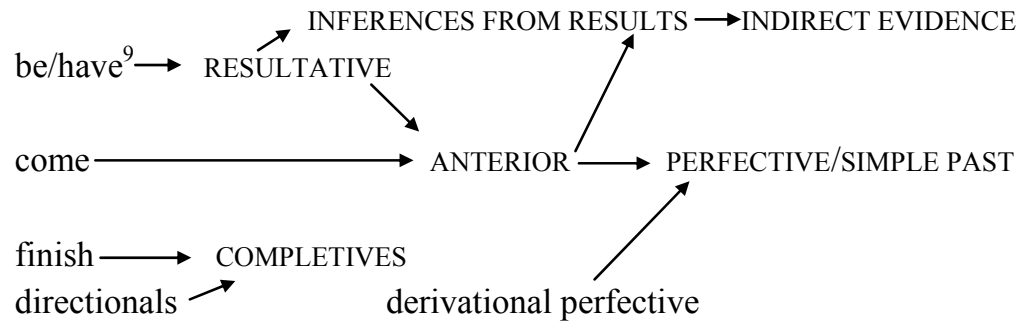

One change encapsulated within the anterior path is the development of resultative expression into anterior meaning, exemplified by the German Perfect. ${ }^{10}$ In the oldest German texts, the auxiliary+Past Participle construction (sein 'be'+Past Participle/ haben 'have' [occasionally eigan 'have'+Past Participle]) was used to express a resultant state (Behaghel 1928, Priebsch \& Collinson

\footnotetext{
9 The lower case labels on the path, represent sources (mostly lexical) for the grammatical categories, which are expressed in small capital letters. The grammatical categories appearing in small caps are the coding categories for grammatical expressions in Gramcats as well.

10 I will follow the convention of punctuation by designating a language specific category with an initial capital letter, whereas a category in its universal sense will be written with an initial lower case letter, in the tradition of Comrie (1976, 1985).
} 
1958). That is, it expressed a present situation as the result of some event or situation in the past, as shown in (6).

(6) Sie eigun mir ginoman lioban druhtin minan. they have me.DAT take.PP beloved lord my 'They have taken from me my beloved lord.'

(Priebsh \& Collinson 1958: 332)

Subsequently in later German, the periphrasis came to signal an anterior meaning, again a past event or situation, the effects of which are felt to extend into the present, a development also attested for the English Perfect (e.g., Carey 1994, 1996).

In one sense, this development, i.e., resultative to anterior, can be viewed as semantic weakening (Bybee \& Pagliuca 1991, Bybee et al. 1994, Givón 1975, Heine \& Reh 1984) because as a resultative, the periphrasis is more definite, referring specifically to a present state of affairs. As an anterior, however, the strict reference to present time is weakened, and instead, the on-going effects of the past event/situation into the PRESENT time are signaled. Thus, semantic weakening is an important mechanism in the development of grammatical expression in language, but a phenomenon not limited to linguistic usage (Bybee 2001: 9, Haiman 1994: 7). Any behavior, if repeated often enough, will begin to lose its original force and meaning, typically broadening its available contexts from one diachronic stage to another.

Semantic weakening is important on the one hand because it accounts for the movement of a gram along a path, but its effects also result in the loss of grammatical expression for some semantic category in a language. That is, as a given grammatical expression moves from one category on a path to the next, it leaves the former category empty of expression. It might thus happen that the category remains without grammatical expression in the language, and the language will cease expressing that meaning. For example, Lancelot 
\& Arnauld (1660) report hodiernal past uses for the French Passé Composé, in which uses it signaled an event or action in the past on the same day as it was reported. This use, however, has not survived into Modern French; instead, if a speaker wants to specify that the past action or event reported occurred on the same day, he/she would have to use some lexical/temporal expression, such as ce matin 'this morning'. Although the loss of a grammatical category along the anterior path in the grammar of a given language after semantic weakening is possible, it would seem to be in fact rather rarer than renewal, as described above, for the grams included in this study.

At the youngest semantic ages along a path, speakers may begin expressing categories, using new periphrastic expressions with elements close to or even identical to their lexical meanings. The specific use of given lexical items in the expression of the youngest semantic categories is neither accidental nor random, but instead, a natural and logical relationship exists between the lexical item used and the grammatical meaning signaled. For example, the crosslinguistic use of go as an element within constructions expressing future time is motivated by the implicational relationship between movement forward and time forward (Bybee et al. 1994: 9-12).

When older semantic categories are abandoned, they may be filled by expressions occupying semantic categories immediately prior on the same path of grammaticization. This type of "refilling" has occurred on the Anterior path in German. In Old High German, the Perfect Periphrasis (Auxiliary+Past Participle) was distinct from the set of synthetic Simple Past forms, i.e., the forms expressing simple past on the Anterior path, simple past being defined as a bounded situation or event reported as past for its oven sake, not being relevant to the present or another time. However, around 1500, the Perfect Periphrasis began to supplant the Simple Past, beginning in the South (Wells 1985: 242). And, although the Simple Past forms have survived in written German, they are rare in most 
varieties of the spoken language where the Perfect Periphrasis dominates. Thus, in Modern German, the Perfect Periphrasis has moved beyond anterior meaning into the simple past semantic category (see Abraham \& Conradie 2001).

Again in this paper, what I want to show is that the more frequent scenario is one where more grammaticized expressions along the anterior path are replaced by less grammaticized ones in the way I have just described. Also, as I stated above, our evidence for this is not direct but inferable from certain synchronic facts about the distribution of morphosyntactic expression in the world's languages, namely layering.

\section{Grams on the Anterior Path}

In this section, we will look at the distribution of grams along the anterior path in (5) from the Gramcats database. Table 1 gives the number of grams for each of the meaning labels on that path and the number of grams that co-occur with another gram of the same meaning in the same language; the last statistic is expressed by a percentage in the final column.

Using the categories listed in the left-most column, we read the data from Table 1 as: There are 36 grams signaling completive in the Gramcats Database. Of those 36 grams, 14, or 38\%, compete (= co-occur) with another completive gram in the same language. ${ }^{11}$

11 It is interesting to note that in Table 1, the earliest semantic age, completive, has slightly lower numbers than the next semantic age. We can attribute this to the fact that completive forms are very young and are still very close to their lexical meanings. They may simply not have been reported as grammatical by the writers of the reference grammars that were used to code data for Gramcats, and therefore were not included in the database. 
Table 1. Distribution of Grams on the Anterior Path

\begin{tabular}{|l|l|l|l|}
\hline \multicolumn{1}{|c|}{ Anterior Path } & & & \\
\hline $\begin{array}{l}\text { Cluster area on path } \\
\text { Moving downward, } \\
\text { the semantic ages go } \\
\text { from less to more } \\
\text { grammaticized) }\end{array}$ & $\begin{array}{l}\text { No. of } \\
\text { grammatical } \\
\text { expressions } \\
\text { in sample }\end{array}$ & $\begin{array}{l}\text { No. of grammatical } \\
\text { expressions that compete } \\
\text { with another form of the } \\
\text { same meaning in the } \\
\text { same language }\end{array}$ & $\begin{array}{l}\text { Percentage of } \\
\text { Competition }\end{array}$ \\
\hline Completive & 36 & 14 & $38 \%$ \\
\hline Young Anterior & 57 & 30 & $52 \%$ \\
\hline Resultative & 22 & 10 & $44 \%$ \\
\hline Old Anterior & 30 & 9 & $30 \%$ \\
\hline Perfective & 38 & 14 & $37 \%$ \\
\hline Simple Past & 25 & 5 & $19 \%$ \\
\hline
\end{tabular}

When we look at the number of grams along the anterior path that co-occur with other grams in the same domain along the path, we see a pattern in which grams at later semantic ages tend to compete less often with other grams; i.e., 52\% of Young Anterior Grams compete with another Young Anterior, while only 19\% of the Simple Past grams compete with another Simple Past. ${ }^{12}$ The data in Table 1 is the result of specialization (Hopper 1991), whereby newly grammaticized material shows more competition, which then tends to reduce as those competing grams continue to develop. ${ }^{13}$ One explanation for the specialization pattern found in Table 1 is renewal. In the earliest semantic categories, a number of coeval constructions develop which come to occupy later semantic positions on a path over time. As the semantics of these developing grams generalize, so too do their grammatical domains, occurring with a greater

12 Young anterior is a finer distinction made of the label Anterior from the path in (5) and it is defined in Bybee et al. (1994: 63) as anteriors that have only anterior as their meaning. Thus, such forms do not have other meanings which might be indicative of grammatical development beyond anterior semantics.

13 Hopper's example is French negation which in older times showed a number of intensifying expressions to the older simple ne negation: ne ... pas, ne ... mie, ne ... gout, and so on. As the periphrastic negative continued to develop, the ne ... pas construction generalized in meaning and replaced the other possible intensifiers. 
number of semantic/syntactic verb types, and thus one member of the competing set will oust other competing members. As we have already observed, once the developing gram moves into a later semantic domain, it might layer with an already existing expression (cf., the Futures in English discussed above). When this type of layering takes place and we are able to analyze one competing expression as being older than another, we know that renewal has taken place.

There is another way of viewing the grams along the anterior path that also suggests a tendency for renewal and those data are given in Table 2.

Table 2. Co-occurrence of Young Anterior Grams and Grams at Later Semantic Ages on the Anterior Path

\begin{tabular}{|c|c|}
\hline Languages with young anterior & Languages with grams at later ages \\
\hline 39 & 34 \\
\hline
\end{tabular}

What the data in Table 2 show is that there are 39 languages in Gramcats that have a young Anterior Gram and that of those 39 languages, 34 have grams somewhere later along the same path. For instance, Balochi (Indo-European/Indo-Iranian) has a gram expressing young anterior as well as grams expressing old anterior and simple past. ${ }^{14}$ Given that young anteriors have been shown to develop into these same later semantic areas, the 39 young anteriors are very likely to layer with or replace already existing grams in those languages where they appear. In other words, since $87 \%$ of the languages with a young anterior have a more advanced gram along the anterior path that the young anterior will at some future time likely layer with or replace, the statistical robustness of renewal is strongly supported.

14 Old anteriors, in contradistinction to young anteriors, are those anteriors that have other uses indicative of further grammatical development, e.g., use in narrative pasts. 


\section{Implications of Competition at Older Semantic Ages: Perfectives}

The ability to infer the tendency for renewal among anterior and related gram senses is strengthened when we focus on the cooccurrence of grams at the most grammaticized ages along that path, where we find that there is good evidence the these co-occurring grams are the result of layering and thus renewal. For instance, in Kanakuru (Chadic), there are two Perfectives, the so-called First and Second Perfectives, shown in (7).

(7) First Perfective: Nà wùpè gám. Mè wùpè gám.

I sold ram we sold ram

'I sold a ram.' 'We sold a ram.'

Kà wùpè gám. $\mathrm{K}$ wùpè gám.

You sold ram you (pl.) sold ram

'You sold a ram.' 'You sold a ram.'

Shì wùpè gám.

you (fem.) sold ram

'You sold a ram.'

À wùpè gám. Wù wùpè gám.

he/she sold ram they sold ram

'He/she sold a ram.' 'They sold a ram.'

Second Perfective: Náá wùpà gám. Mèn wùpà gám. I sold ram we sold ram 'I sold a ram.' 'We sold a ram.'

Káí wùpà gám. Káá wùpà gám.

You sold ram you (pl.) sold ram

'You sold a ram.' 'You sold a ram.'

Shíjí wùpà gám.

you (fem.) sold ram

'You sold a ram.' 
Shíi wùpà gám. Wún wùpà gám. he sold ram they sold ram 'He sold a ram.' 'They sold a ram.' Shéé wùpà gám. she sold ram

'She sold a ram.'

(Newman 1974: 45)

One piece of evidence that the First Perfective is older than the Second is seen in fact that the set of Pronouns for the First Perfective do not distinguish between $3^{\text {rd }}$ singular masculine and feminine as pronouns normally do in Kanakuru. Given the persistence of masculine and feminine marking on pronouns in all other areas of Kanakuru grammar, one might suspect that phonological attrition (and/or morphological merger) has resulted in the two forms becoming non-distinct, a process which occurs only after some time.

Better evidence for the more advanced grammatical age of the First Perfective comes from comparing it to the Second Perfective, which shows both syntactic and morphophonological evidence of its younger grammatical age. First, the Second Perfective is smaller in its syntactic range, occurring in negative, relative and emphatic clauses, a distribution reminiscent of the uses of auxiliary $d o$ in earlier stages of English (Rissanen 1999, Visser 1969). Additional evidence that the Second Perfective is the result of a more recent grammaticization process is its relatively longer form. This is manifest in two ways. First, the set of Pronouns used to signal the Second Perfective are long, carrying high tone; note that the set of pronouns for the First Perfective are short with low tone, and in contrast to the First Perfective, the Second Perfective Pronouns distinguish masculine and feminine forms. Also, the verb stem in the Second Perfective carries an obligatory suffix $-a$, so that in effect the Second Perfective is periphrastic. The syntactically tighter form of the First Perfective compared to the looser periphrastic form of the 
Second Perfective also supports the assertion that it is younger since periphrasis is more often associated with less-grammaticized stages. $^{15}$

In Alyawarra (Pama-Nyugan/Arandic), there are two perfective markers, ika and alh- (Bybee et al. 1994: 333, based on Yallop 1977: 57, 62). The discussion of these grams in Yallop supports the idea that of these $i k a$ is the older and that alh- has more recently developed into a perfective. First consider that $i k a$ belongs to a set of tense/aspect inflections referred to as Declarative Inflections by Yallop (1977); these are given in (8).

(8) Declarative Inflections (Yallop 1977: 57)

-ika past

-ina past continuous

-ikala past perfect

-ima present

-iyla present continuous

Alh-, on the other hand, is referred to as a "compound verb" construction, along with a few other such verbs, given in (9).

(9) Compound Verbs (from Yallop 1977: 62) ${ }^{16}$

alhima go, walk, move

alpima go away, go back

anima sit (often merely 'be')

ayntima lie (often merely 'be')

15 One must be cautious of relying too heavily on this line of argumentation, however, because it can be viewed as circular: one invokes the products of grammaticization to argue for grammaticization (Campbell 2001, Janda 2001, Newmeyer 2001). However, given the extensive cross-linguistic correlation between grammatical age and grammatical form in terms of periphrasis versus affixation (Bybee et al. 1994, Dahl 1985), it seems reasonable to invoke that universal trend as another piece of evidence in the dating of grams.

16 The verbs are given in the base form with the present tense marker -ima. 
Yallop reports the the use of alh- with the ligative -iy- as perfective (punctilear in his terminology), but that often the lexical meaning of the verb is apparent in the sense of "went and did something". From his examples, however, it is clear that alh-, while clearly fortifying the perfectivity of a given situation, is not doing so alone. Instead, in its perfective functions co-occur with the older $i k a$ suffix; thus quite literally layering with it to build a new perfective nuance, an example of which is given in (10).

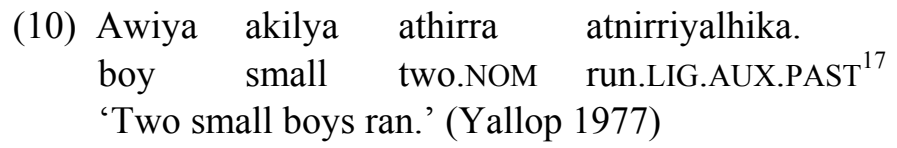

As a final remark on the Alyawarra situation, we can note the lexical transparency of alh- which also supports it relatively younger age, since the older a given gram is the more difficult it is to recover its lexical source. Also, we can note that -ika goes back to common Arandic, having cognate grams in Eastern, Southern and Western Arandic (Yallop 1977: 58), which suggests its length of time in the language goes back to a pre-Alyawarra split.

In Mwera (Bantu), there are three grams listed in Bybee et al. (1994: 333) as marking perfective: the suffix -ile, the auxiliary $\bar{a}$ and the auxiliary $\bar{a} c i$ (Harries 1950: 79-83, 95-97). Of these, the suffix ile is the oldest, going back to common Bantu, cf., similar forms in Swahili and Bemba, and the reconstruction of that form for Great Lakes Bantu in Nurse \& Muzale 1999). The other perfectives, which are actually based on the daily cycle, indicating actions that took place before the day of speech, are analyzed as relatively younger based on the fact that they are auxiliary verbs employed in periphrastic constructions, cf. the discussion of periphrasis in the Kanakuru example above. Examples of these periphrastic constructions

17 The gloss LIG here is 'ligative', the term used in Yallop (1977). 
in Mwera are given in (11).

\begin{tabular}{llll} 
(11) & \multicolumn{2}{c}{ ci Perfective } & \multicolumn{2}{c}{$\bar{a}$ Perfective } \\
\cline { 2 - 2 } nācipi & ga & nāpi & gile \\
I & wanted & I & wanted \\
gwācipi & ga & gwāpi & gile \\
you & wanted & you & wanted \\
ācipi & ga & āpi & gile \\
he/she & wanted & he/she & wanted \\
twācipi & ga & twāpi & gile \\
we & wanted & we & wanted \\
mwācipi & ga & mwāpi & gile \\
you (pl.) & wanted & you (pl.) & wanted \\
ẉācipi & ga & wāpi & gile \\
they & wanted & they & wanted
\end{tabular}

In fact, it is quite likely that $\bar{a} c i$ is itself a periphrasis made up of the $\bar{a}$ of the other perfect construction together with the auxiliary $-c i$ of the so-called "immediate past" (Harries 1950: 94-95). We can also note that the perfect made with the auxiliary $\bar{a}$ derives its perfectivity in part from its use with -ile in the example in (11), similar to the situation of layering with the Alyawarra periphrasis just discussed. A final piece of evidence that -ile is older than the periphrastic perfectives shown in (11) comes from the fact that the suffix -ile is involved in a number of morphophonemic alternations, indicating a relatively older grammatical age since it must be that the suffix has been in existence long enough for the phonetic material in the stem and the host to begin to fuse (see Bybee et al. 1994: Chapter 4 on the use of morphophonological alternation as a heuristic in the dating of grams generally).

Due to the limits of scope and space, I am not able to provide

18 My terms. 
data on each of the 14 co-occurring grams for perfective from Gramcats. However the randomly selected examples discussed here support the hypothesis that when we find multiple grams at later semantic domains along the anterior path, they show evidence of layering, and thus the case for renewal is made stronger. Obviously, a finer-grained analysis of grams along the anterior path would flesh the analysis out and provide further testing of this hypothesis. I will conclude by offering that analysis of very grammaticized areas on other paths of development support the general hypothesis here. Bybee et al. (1994: 144), for instance, have shown that the cooccurrence of present grams, i.e. those indicating an action, event or state as holding true at the moment of speaking, is the result of layering due to the grammaticization of earlier progressive grams and already-existing present grams. ${ }^{19}$

\section{Conclusion}

In this paper, I have set out to make the case that there is a rather strong tendency for renewal among grams expressing anterior and diachronically related meanings, a set of relationships I have referred to as the anterior path of grammaticization. As I was able to show, it is clear that at early domains on that path, there is considerable competition among grams but that as those grams develop, they have a tendency to expand their domain and oust earlier competitors. At the latter domains, then, the competition is not among chronologically coeval grams, but instead represents layering, i.e., older and newer waves of grammaticization, which is the outcome of renewal. The renewal scenario is supported by the

19 Progressive is defined as an event on-going at some reference time. Progressives in which the reference time is the moment of speech can develop present meanings if they begin to signal habitual meanings in addition to progressive (see e.g., Comrie 1976: 38-40). 
very robust stacking up of grams along the anterior path, in which grams expressing young anterior almost always co-exist with grams at later stages on the same path. Given the axiom that language changes and the fact that young anterior grams develop into those same later semantic areas that are already occupied by other grams (and that young anteriors do not evolve into, say, future markers), the case for renewal is strong.

More broadly, a tendency for renewal suggests that as language changes, there is a tendency for the shape of its grammar to remain somewhat stable, although certainly new grammatical categories may arise and others may wane over time. While the notion of stability in grammar is not new, few data-driven studies of the phenomenon have been offered. Therefore, this study of data concerning anterior and related meanings in Gramcats, and the ability to extrapolate those findings onto the world's languages, offers an important step toward the testing of this hypothesis in other verbal and non-verbal domains as well as a means of understanding the universality of languages in the diachronic realm.

\section{References}

Abraham, W. \& C. Conradie. 2001. Präteritumschwund und Diskursgrammatik:

Präteritumschwund in Gesamteuropäischen Bezügen-Areale Ausbreitung, Heterogene Entstehung, Parsing Sowie Diskursgrammatische Grundlagen un Zusammenhänge. Amsterdam: Benjamins.

Behagel, O. 1928. Geschichte der Deutchen Sprache. Berlin: Walter de Gruyter \& Co.

Bybee, J., W. Pagliuca, \& R. Perkins. 1991. Back to the Future. In E. Traugott \& B. Heine (eds.), Approaches to Grammaticalization 2, $17-$ 58. Amsterdam: Benjamins.

Bybee, J., R. Perkins, \& W. Pagliuca. 1994. The Evolution of Grammar: Tense, Aspect and Modality in the Languages of the World. Chicago, 
158 The Universal Tendency for Renewal among

IL: University of Chicago Press.

Bybee, J. 2001. Phonology and Language Use. Cambridge: Cambridge University Press.

Campbell, L. (ed.). 2001. Grammaticalization: A Critical Assessment. Language Sciences 23, 2-3.

Carey, K. 1994. The Grammaticalization of the Perfect in Old English: An

Account Based on Pragmatics and Metaphor. In W. Pagliuca (ed.), Perspectives on Grammaticalization 105-117. Amsterdam: Benjamins. . 1996. Subjectification and the Development of the English

Perfect. In D. Stein \& S. Wright (eds.), Subjectivity and Subjectivisation 84-102. Cambridge: Cambridge University Press.

Comrie, B. 1976. Aspect. Cambridge: Cambridge University Press. . 1985. Tense. Cambridge: Cambridge University Press.

Dahl, Ö. 1985. Tense and Aspect Systems. Oxford: Blackwell. . 2000. Tense and Aspect in the Languages of Europe. Empirical Approaches to Language Typology, Eurotype 20-26. Berlin: Mouton de Gruyter.

Fleischman, S. 1982. The Future in Thought and Language. Cambridge: Cambridge University Press.

Gabelentz, G. 1891. Die Sprachwissenschaft. Ihre Aufgaben, Methoden, und Bisherigen Ergebnesse. Leipziz: Weigel.

Givón, T. 1975. Serial Verbs and Syntactic Change: Niger-Congo. In C. Li (ed.), Word Order and Word Order Change 47-112. Austin, TX: University of Texas Press.

Haiman, J. 1994. Ritualization and the Development of Language. In W. Pagliuca (ed.), Perspectives on Grammaticalization 3-28. Amsterdam: John Benjamins.

Harries, L. 1950. Grammar of Mwera. Johannesburg: Witwatersrand University Press.

Heine, B. \& M. Reh. 1984. Grammaticalization and Reanalysis in African Languages. Hamburg: Helmut Buske Verlag.

Heine, B., U. Claudi, \& F. Hünnemeyer. 1991. Grammaticalization: A Conceptual Framework. Chicago, IL: University of Chicago Press. 
Hodge, C. 1970. The Linguistic Cycle. Language Sciences 13, 1-17.

Hopper, P. 1991. On Some Aspects of Grammaticization. In E. Traugott \&

B. Heine (eds.), Approaches to Grammaticalization 2, 17-35. Amsterdam: Benjamins.

Hopper, P. \& E. Traugott. 2003. Grammaticalization. Cambridge: Cambridge University Press.

Janda, R. 2001. Beyond "Pathways" and "Unidirectionality": On the Discontinuity of Language Transmission and the Counterability of Grammaticalization. Language Sciences 24, 265-340.

Lancelot, C. \& A. Arnauld. 1660. Grammaire général et raisonée. Paris: Pierre le Petit.

Meillet, A. 1912. L'evolution des formes grammaticales. Scientia 12.26, 6. (Reprinted in A. Meillet. 1948. Linguistique historique et linguistique general 1, 130-148. Paris: Edouard Champion.)

Mitchell, B. 1985. Old English Syntax, Two Vols. Oxford: Clarendon Press.

Newman, P. 1974. The Kanakuru Language. Leeds: The Institute of Modern English Language Studies.

Newmeyer, F. 1998. Language Form and Language Function. Cambridge: Cambridge University Press. . 2001. Deconstructing Grammaticalization. In L. Campbell (ed.), Grammaticalization: A Critical Assessment. Language Sciences 23, 187-229.

Nurse, D. \& H. Muzale. 1999. Tense and Aspect in Lacustrine Languages. In J. Hombert \& L. Hyman (eds.), Bantu Historical Linguistics: Theoretical and Empirical Perspectives 517-544. Stanford, CA: CSLI Publications.

OED Oxford English Dictionary. On-line Version Licensed to Users at Milner Library, Illinois State University, Updated Version of 2005.

Priebsh, R. \& W. Collinson. 1958. The German Langauge (4 $4^{\text {th }}$ Edition). London: Faber \& Faber.

Quirk, R., S. Greenbaum, G. Leech, \& J. Swartik. 1985. A Grammar of Contemporary English. New York \& London: Longman.

Rissanen, M. 1999. Syntax. In R. Lass (ed.), The Cambridge History of the 
160 The Universal Tendency for Renewal among

English Language 3, 1479-1776. Cambridge: Cambridge University Press.

Traugott, E. \& R. Dasher. 2002. Regularity in Semantic Change. Cambridge: Cambridge University Press.

Visser, F. 1969. An Historical Syntax of the English Language. Leiden: E.J. Brill.

Wells, C. 1985. German: A Linguistic History to 1945. Oxford: Clarendon Press.

Yallop, C. 1977. Alyawarra: An Aboriginal Language of Central Australia. Canberra: Australian Institute of Aboriginal Studies.

Zupitza, J. 1880. AElfrics Grammatik und Glossar. Berlin: Weidmannsche Buchhandlung. 